\title{
Physiological and Ethological Effects of Fluoxetine, A Study Using Ants as Biological Models
}

\author{
Marie-Claire Cammaerts ${ }^{1} \&$ David Cammaerts \\ ${ }^{1}$ Faculté des Sciences, Université Libre de Bruxelles, Av. F. Roosevelt, Bruxelles, Belgium \\ Correspondence: Marie-Claire Cammaerts, Faculté des Sciences, DBO, CP 160/12, Université Libre de Bruxelles, \\ 50 Av. F. Roosevelt, 1050, Bruxelles, Belgium. E-mail: mtricot@ulb.ac.be
}

Received: December 12, 2014 Accepted: December 24, 2014 Online Published: January 8, 2015

doi:10.5539/ijb.v7n2p1 URL: http://dx.doi.org/10.5539/ijb.v7n2p1

\begin{abstract}
Using ants as biological models, we showed that fluoxetine (the active substance of the most consumed antidepressants) largely affects the individual's physiology and behavior. It increases sinuosity of movement, decreases precision of reaction and response to pheromones, decreases food consumption and brood caring, and induces aggressiveness towards nestmates while decreasing that towards aliens. Under fluoxetine consumption, ants lost their olfaction and their learning ability, having also lower cognitive ability. There is no habituation to, and no dependence on, fluoxetine consumption, which effects vanish in two or two and a half days. Attention should be paid whenever that drug is used, not only for the humans but also for all the organisms living on field and depending on natural water. A future work will examine antidepressants free of fluoxetine, hoping that they could advantageously replace those containing that harmful substance.
\end{abstract}

Keywords: activity, aggressiveness, cognition, dependence, food consumption, memory

\section{Introduction}

In some rivers (for instance, in River St Laurent, Canada), fishes appeared to present aberrant behavior. Fifty trouts maintained in St Laurent water mixed to that coming from Montreal city presented, after three months, small amounts of antidepressants in their liver, brain and muscles, as well as some decrease of their brain synaptic activity (Sauvé, 2011). Similar observations were made in Wisconsin, USA, on minnows living in water contaminated by antidepressants (Klaper, 2013). Males often stayed under stones, no longer approached females, took more time for capturing preys, and under larger amounts of drugs, aggressed congeners, and even killed females. Also, females laid fewer eggs, and young minnows behaved as being anxious. Such aberrant behavior could be explained by changes observed in the young minnows' brains (Klaper, 2013). Apart this, many other drugs used by humans presently contaminate natural water (Lecomte, 2014).

Antidepressants are present in natural water because they are presently largely consumed by humans, are eliminated by the kidneys, and then transported into natural water via sewerage systems. There exist four kinds of such drugs. The 'IMAO' inhibit the monoamine oxidize and are now given only in hospitals, thus in limited amounts. The 'ATC' are tricycle ones, and inhibit several neurotransmitters. The 'ISRS' inhibit the recapture of serotonin, while the 'IRSNa' inhibit the recapture of serotonin and noradrenalin (Antidépresseur, ND). Acting on the recapture of neurotransmitters, they may have unwanted effects on humans. Effectively, several studies revealed adverse effects of antidepressants: let us cite, among others, the works of Parent (2011), Simon (2002), Cipriani et al. (2009), and Lane (2009). However, not all potential adverse effects have been examined for the humans as well as for other living organisms, and, concerning the humans, it is possible that not all the obtained results have been revealed.

All these information leaded us to presume that some danger could exist for living organisms, especially aquatic ones, when they are exposed to those substances. Aquatic macroinvertabrates could be exposed to antidepressants through the release of these substances with untreated or inefficiently teated waste water. Aquatic macroinvertebrates play such an important role in the ecology of water bodies, occupying a variety of ecological niche and performing a huge variety of behaviors, so that any modifications of these behaviors could lead to significant changes in the trophic relationship between organisms of the aquatic fauna. Complex equipment is required for studying the behavior of aquatic invertebrates in laboratory conditions. So, we use ants as biological models to study the effects of antidepressants on animals' behavior and physiology. 
Presently, the ISRS are the most commonly consumed antidepressants, and their most commonly used active substance is fluoxetine. We examine thus, in the present work, some effects of that substance, and will study in a future work those of an 'ATC' and an 'IRSNa', each time using ants as biological models.

As most of the biological processes are similar for all animals, including humans (i.e. genetics, metabolism, nervous cells functioning), a lot of invertebrates and vertebrates can be used as models for studying biological questions (Kolb \& Whishaw, 2002; Whener \& Gehring, 1999; Russell \& Burch, 2014). Invertebrates are more and more used as biological models because they offer scientists many advantages, among others a short life cycle, a simple anatomy, and being available in large numbers (Wolf \& Heberlein, 2003, Sovik \& Barron, 2013). Some species became largely used as biological models, for instance, the flatworm Dendrocelium lacteum, the nematode worm Caenorhabdotes elegans, the mollusk Aplysia californica, the beetle Tribolim castaneum, the fruit fly Drosophila melanogaster, and the domestic bee Apis mellifera. Among the invertebrates, insects, especially social hymenoptera and among them, bees, are advantageously used as biological models (André, Wirtz, \& Das, 2008; Abramson, Wells, \& Janko, 2007).

Ants also could be used. Colonies containing thousands of ants can easily be maintained in laboratories, at low cost and very conveniently, throughout the entire year. Ants are also among the most evolved organisms as for their morphology, their physiology, their social organization and their behavior. They are among the most morphologically elaborate hymenoptera, having indeed a unique resting position of their labium, mandibles and maxilla (Keller, 2011), as well as a lot of glands emitting numerous, efficient compounds (Billen \& Morgan, 1998). Their societies are highly organized with a strong division of labor, an age-based polyethism and a social regulation (Holldobler \& Wilson, 1990). Their behavior is highly developed: they care for their brood, build sophisticated nests, chemically mark the inside of their nest, and, differently, their nest entrances, their nest surroundings and their foraging area (Passera \& Aron, 2005). They generally use an alarm signal, a trail pheromone, and a recruitment signal (Passera \& Aron, 2005); they are able to navigate using memorized visual and olfactory cues (Cammaerts, 2012, and references therein); they efficiently recruit nestmates where, when and as long as it is necessary (Passera, 2006), and, finally, they clean their nest and provide their area with cemeteries (Keller \& Gordon, 2006). So, according to the complexity of their society and their behavior, it looks reasonable to use ants as biological models for studying physiological and ethological effects of neuronal active substances.

We have largely studied the ant's species belonging to the genus Myrmica, and above all Myrmica sabuleti Meinert 1861. We know its ecological characteristics, eye morphology, visual perception, navigation system, visual and olfactory conditioning capabilities, and recruitment strategy (Rachidi, Cammaerts, \& Debeir, 2008; Cammaerts, 2008; Cammaerts \& Rachidi, 2009; Cammaerts, Rachidi \& Cammaerts, 2011). The ontogenesis of cognitive abilities of Myrmica species, including M. sabuleti, has also been approached (Cammaerts \& Gosset, 2014b, Cammaerts, 2013a, 2013b, 2014a, 2014b). Studies on the impact of age, activity and diet on $M$. ruginodis' conditioning capability (Cammaerts \& Gosset, 2014a) leaded to presume that M. sabuleti could be a good biological model. This was confirmed by the study of the effects of caffeine, theophylline, cocaine, and atropine (Cammaerts, Rachidi \& Gosset, 2014b), of nicotine (Cammaerts, Gosset, \& Rachidi, 2014a), and of morphine and quinine on M. sabuleti (Cammaerts \& Cammaerts R., 2014). The results of these studies brought information and precision about effects of the alkaloids on humans. We thus have compiled a sufficient amount of information about the behavior and physiology of that species to be able to conduct a similar analysis about potential adverse physiological and ethological effects generated by fluoxetine consumption.

\section{Experimental Planning}

The 19 following behavioral and physiological traits were assessed on two colonies of $M$. sabuleti before and after they consumed fluoxetine. A third colony was used to provide 'alien workers'. Most of these traits had previously similarly been examined while studying effects of alkaloids and drugs (see references at the end of the 'Introduction' section).

1 - the locomotion (and thus the general activity) through the ants' linear and angular speed,

2 - the precision of reaction through the orientation towards a source of their alarm pheromone,

3 - the response to pheromones through the trail following behavior,

4 - the "audacity" through the numbers of ants coming onto a test apparatus,

5 - food consumption through the numbers of ants coming onto meat food,

6 - the tactile sensation (or "pain" perception) through the ants' behavior in an uncomfortable situation,

7 - cognition through the ability in performing a task requiring cognition (moving through chicanes),

8 - the potential aggressiveness against nestmates through ants' behavior in the course of dyadic encountering, 
9 - the expected aggressiveness against alien ants through ants' behavior in the course of dyadic encountering,

10 - the caring behavior through the behavior in front of larva removed from the nest,

11 - the visual perception through the distinguishing of two colors,

12 - the olfactory perception through the distinguishing of two odors,

13 - the visual learning ability through the acquisition of a visual conditioning,

14 - the visual memory through the duration of the remembering a learned visual cue,

15 - the olfactory learning ability through the acquisition of an olfactory conditioning,

16 - the olfactory memory through the duration of the remembering a learned olfactory cue,

17 - the habituation to the drug consumption through the speed of movement and the orientation to an alarm signal, seven days after continuous drug consumption,

18 - the dependence on drug consumption through the numbers of ants choosing food containing the drug,

19 - the decrease of the effects of fluoxetine after its consumption end, through the ants' sinuosity of movement and orientation to an alarm signal after that fluoxetine had been removed from the food.

\section{Material and Methods}

\subsection{Collection and Maintenance of the Ants}

The study was made on three colonies of M. sabuleti, two ones (labeled 1 and 2) having been devoted to the experimental work while the third one only furnished the 'alien workers' required in one experiment. The three colonies were collected in summer 2013 in an abandoned sandstone quarry located at Treignes (Ardenne, Belgium). The ants were nesting under stones, in a field covered with small plants and brushes. The collected colonies were demographically similar, containing about 600 workers, one or two queens and brood at larval and nymphal stages. They were maintained in the laboratory in artificial nests made of one to three glass tubes half-filled with water, with a cotton-plug separating the ants from the water. These glass tubes were deposited in trays $(34 \mathrm{~cm} \times 23 \mathrm{~cm} \times 4 \mathrm{~cm})$, the sides of which were covered with talc to prevent the ants from escaping. The trays served as foraging areas, food being delivered into them. The ants were fed with sugar-water provided ad libitum in a small glass tube plugged with cotton, and with pieces of Tenebrio molitor (Linnaeus 1758) larva provided twice a week on a glass slide. Temperature was maintained between $18^{\circ} \mathrm{C}$ and $22^{\circ} \mathrm{C}$, humidity at about $80 \%$, these conditions remaining constant over the course of the study. Lighting had a constant intensity of 330 lux while caring for the ants, training and testing them. During other time periods, the lighting was dimmed to 110 lux. The ambient electromagnetic field had an intensity of 2-3 $\mu \mathrm{W} / \mathrm{m}^{2}$.

\subsection{Acquisition of Fluoxetine, Realization of Aqueous Solutions for Ants}

Five hundred milligrams of fluoxetine, produced by the manufacturer CERTA, were provided by the pharmacist J. Cardon (1050 Brussels). The product was provided as a white bright powder, at the highest level of purity possible. According to the amount of fluoxetine given to depressive humans, and the quantity of water these humans drink, it could be established that the most appropriate solution of fluoxetine would be $1 \mathrm{mg}$ of fluoxetine into $1,000 \mathrm{mg}$ of water. Therefore, $30 \mathrm{mg}$ of fluoxetine were weighted using a precision balance, and were then dissolved in $30 \mathrm{ml}$ (=30,000 $\mathrm{mg}$ of water) of a saturated solution of brown sugar, the ants' usual liquid food. The concentration in drug of the final solution was thus $30 \mathrm{mg}$ in $30 \mathrm{ml}$ of water, so $1 / 1,000$. This solution was given to the ants, like their usual liquid food, in a small glass tube plugged with cotton, the cotton being refreshed each two days and the entire solution renewed each 14 days. It was checked each day if ants actually consumed the given liquid food containing fluoxetine.

\subsection{Orientation, Linear and Angular Speed $(1,2)$}

Ants' linear and angular speed was assessed for detecting excitation or sleepiness in the animals. This assessment was made on ants freely moving on their foraging area. Ants' orientation towards an isolated congener's head allows measuring the ants' precision of reaction. An isolated worker's head, with widely opened mandibles, is a source of alarm pheromone identical to that of an alarmed worker, in terms of the dimensions of the emitting source (the mandibular glands' opening) and of the quantity of pheromone emitted (Cammaerts-Tricot, 1973). Each time, such assessment was made on ants of the two nests having never consumed fluoxetine, then on ants of these two nests having consumed the drug during two days. For each assessment, the movement of ten ants of each nest ( $\mathrm{n}=20$ ants) was analyzed. 

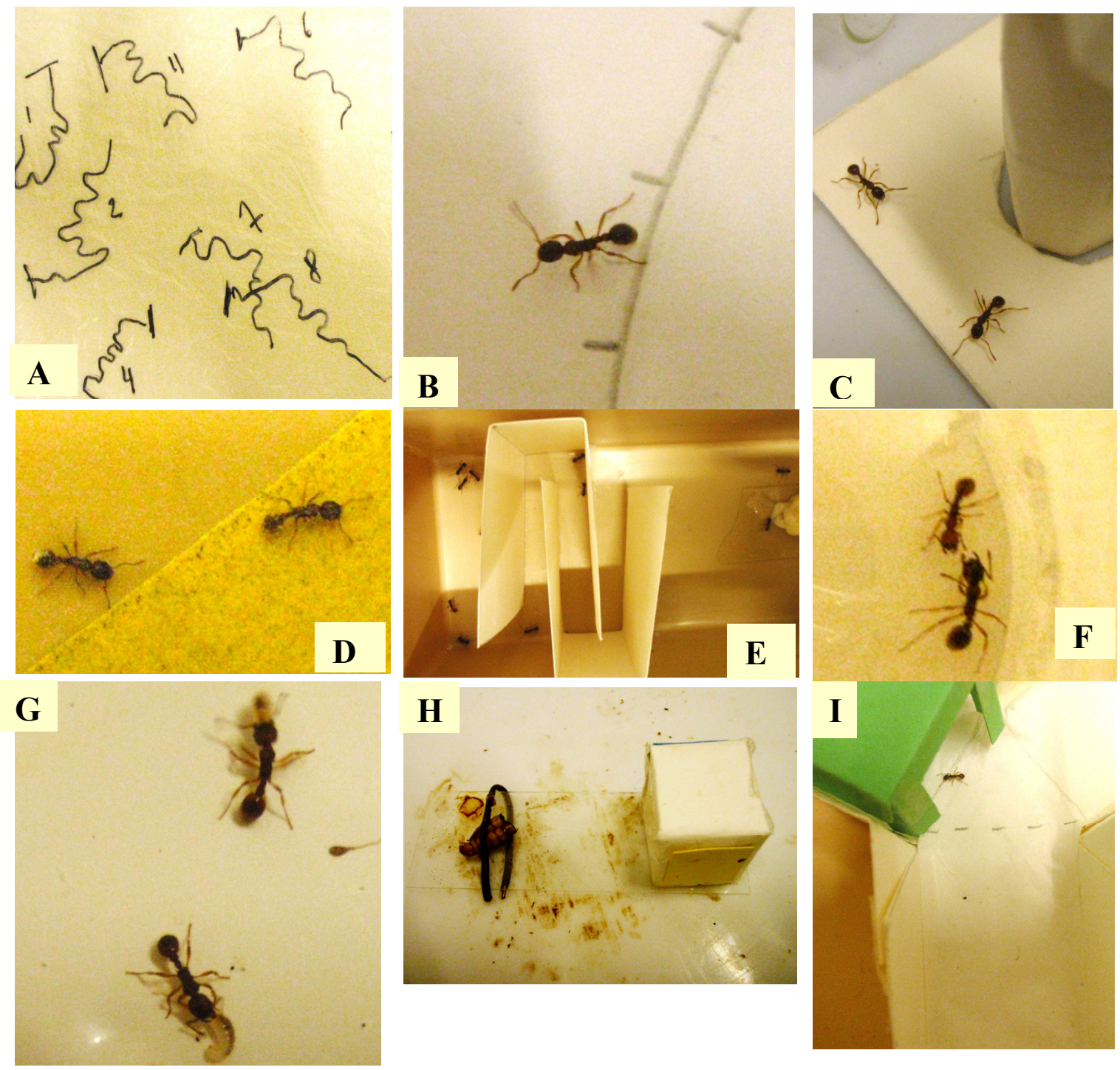

Figure 1. Some views of the experiments

A: ants' trajectories under fluoxetine consumption; the trajectories were sinuous. B: ants' trail following behavior under fluoxetine consumption; ants failed in well following the trail. C: ants under fluoxetine consumption, and confronted with a risky apparatus; as without this drug, they were not inclined to move on the apparatus. D: ants under normal diet, confronted with a very rough substrate; the ant on the right presented difficulties when moving on the rough substrate. $\mathbf{E}$ : ants under normal diet set in front of chicanes; some of them could find their way through the chicanes, up to a larger area. F: two nestmates, under fluoxetine consumption, in front of one another; they opened their mandibles, a rather aggressive behavior. G: caring of larvae by ants under normal diet; the ants gently pulled up the larvae and quickly brought them into the nest. H: experimental design used for assessing the ants' visual perception, under fluoxetine consumption; a cube with a blue and a yellow face was set four $\mathrm{cm}$ from the ants' meat food. I: an ant among twenty others, under fluoxetine consumption, tested in a Y apparatus for assessing the ants' visual learning ability

Trajectories were recorded manually, using a water-proof marker pen, on a glass slide placed horizontally $3 \mathrm{~cm}$ above the area where the tested individuals were moving. A metronome set at 1 second was used as a timer for assessing the total time of each trajectory. Each trajectory was recorded during 5 to 10 seconds or until the ant reached the stimulus. All the trajectories were then traced, with a water-proof marker pen, onto transparent polyvinyl sheets (Figure 1A) using the glass slide as the reference model, and the polyvinyl sheets were affixed to a PC monitor screen. The trajectories were analyzed using specifically designed software (Cammaerts, Morel, Martino \& Warzée, 2012) so that the trajectory parameters could be quantified. 
The three parameters used to characterize the trajectories are defined as follows:

The linear speed $(\mathrm{V})$ of an animal is the length of its trajectory divided by the time spent moving along this trajectory. It was measured in $\mathrm{mm} / \mathrm{s}$.

The angular speed (S) (i.e. the sinuosity) of an animal's trajectory is the sum of the angles, measured at each successive point of the trajectory, made by the segment 'point $\mathrm{i}$ - point $\mathrm{i}-1$ ' and the segment 'point $\mathrm{i}$ - point $\mathrm{i}+$ 1', divided by the length of the trajectory. This variable was measured in angular degrees $/ \mathrm{cm}$ (= ang. deg. / cm).

The orientation $(\mathrm{O})$ of an animal towards a given point (here an ant's head) is the sum of the angles, measured at each successive point of the registered trajectory, made by the segment 'point $i$ of the trajectory - given point' and the segment 'point $\mathrm{i}$ - point $\mathrm{i}+1$ ' divided by the number of measured angles. This variable was measured in angular degrees (= ang. deg). When such a variable $(\mathrm{O})$ equals $0^{\circ}$, the observed animal perfectly orients itself towards the point; when $\mathrm{O}$ equals $180^{\circ}$, the animal fully avoids the point; when $\mathrm{O}$ is lower than $90^{\circ}$, the animal has a tendency to orient itself towards the point; when $\mathrm{O}$ is larger than $90^{\circ}$, the animal has a tendency to move in a direction that deviates from the point.

Each distribution of 20 measurements was characterized by its median and its quartiles (since being not Gaussian; Table 1, table lines 1,2), and the distribution of values obtained for ants having consumed fluoxetine was statistically compared to that previously obtained for the ants having never consumed that drug, using the non-parametric $\chi^{2}$ test (Siegel and Castellan, 1989). The significance threshold was set to $\alpha=0.05$.

Table 1. Effect of fluoxetine on five ants' physiological traits

\begin{tabular}{|c|c|c|c|c|}
\hline Traits & Variable assessed & No drug consumed & Drug consumed & Statistics \\
\hline \multirow[t]{2}{*}{ Activity $n=20$} & Linear speed $(\mathrm{mm} / \mathrm{sec})$ & $14.9(14.2-16.8)$ & $13.1(11.6-14.6)$ & $0.01<\mathrm{P}<0.02$ \\
\hline & Sinuosity (ang.deg./cm) & $113(97-129)$ & $149(129-172)$ & $\mathrm{P}<0.001$ \\
\hline $\begin{array}{l}\text { Precision of } \\
\text { reaction } n=20\end{array}$ & $\begin{array}{l}\text { Orientation to an alarm } \\
\text { signal (ang.deg.) }\end{array}$ & $34.5(29.9-50.7)$ & $69.9(53.7-82.5)$ & $0.001<\mathrm{P}<0.01$ \\
\hline Response to & Trail following behavior & C: $1(1-1.3)$ & $C: 1(1-1)$ & NS \\
\hline pheromones $n=40$ & $\left(\mathrm{n}^{\circ}\right.$ of arcs walked) & $\mathrm{T}: 12.0(7.0-16.3)$ & $\mathrm{T}: 3.5(2.0-6.3)$ & $\mathrm{P}<0.001$ \\
\hline "Audacity" $n=20$ & $\begin{array}{l}\mathrm{N}^{\circ} \text { of ants on a tower } \\
\text { (mean, extremes) }\end{array}$ & $1.35(0-2)$ & $1.62(0-4)$ & $\mathrm{P}=0.0858$ \\
\hline $\begin{array}{l}\text { Food consumption } \\
\mathrm{n}=20\end{array}$ & $\begin{array}{l}\mathrm{N}^{\circ} \text { of ants eating meat } \\
\text { (mean, extremes) }\end{array}$ & $2.2(1-4)$ & $0.46(0-2)$ & $\mathrm{P}=0.000002$ \\
\hline
\end{tabular}

\subsection{Trail Following Behavior (3)}

This behavior was assessed for examining the ants' response to a pheromone. The trail pheromone of Myrmica ants is produced by the workers' poison gland. Ten of these glands were isolated in $0.5 \mathrm{ml}(500 \mu \mathrm{l})$ hexane and stored for $15 \mathrm{~min}$ at $-25{ }^{\circ} \mathrm{C}$. To perform one experiment, $0.05 \mathrm{ml}(50 \mu \mathrm{l})$ of the solution was deposited, using a metallic normograph pen, on a circle $(\mathrm{R}=5 \mathrm{~cm})$ pencil drawn on a piece of white paper and divided into 10 angular degrees arcs (= ang. deg.). One minute after being prepared, the piece of paper with the artificial trail was placed in the ants' foraging area. When an ant came into contact with the trail, its movement was observed (Figure 1B). Its response was assessed by the number of arcs of 10 angular degrees it walked without departing from the trail, even if it turned back while walking on the trail. If an ant turned back when coming in front of the trail, its response was assessed as "zero arc walked"; when an ant crossed the trail without following it, its 
response equaled "one walked arc". Before testing the ants on a trail, they were observed on a "blank" circumference imbibed with $50 \mu 1$ of pure hexane, and the control numbers of walked arcs were so obtained (Table 1, table line 3, $\mathrm{C}=$ control, $\mathrm{T}=$ test). On such experimental trails, Myrmica workers do not deposit their trail pheromone because they do so only after having found food or a new nest site. Each time, these manipulations were made firstly on ants having never consumed fluoxetine, then on the same colony having consumed this drug for 3 days. For each control and test experiment, 20 individuals of each two used colonies were observed $(\mathrm{n}=40)$. Each distribution of values was characterized by its median and its quartiles (since being not Gaussian; Table 1, table line 3). The distributions of values obtained for ants having consumed fluoxetine were compared to the corresponding ones obtained for ants having never consumed this substance, by using the non parametric $\chi^{2}$ test (Siegel \& Castellan, 1989).

\subsection{Ants' "Audacity" (4)}

Before the ants consumed fluoxetine, and three days after they had consumed that drug, a cylindrical tower built in

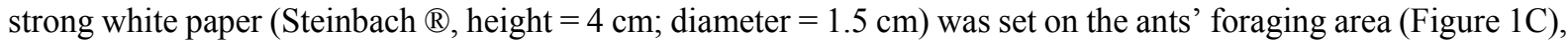
and the ants present on it, at any place, were counted 10 times, in the course of 10 min. The mean and the extreme values of the obtained values were established each time and the two series of values were compared using the non parametric Mann-Whitney U test (Siegel \& Castellan, 1989; Table 1, table line 4).

\subsection{Ants' Food Consumption (5)}

Before the ants consumed fluoxetine, and after they had consumed that drug for three days, the workers present on the meat food (pieces of T. molitor larva) at a time ants must be fed were counted 10 times in the course of 10 min. The numbers obtained for the two kinds of food intake (with no drug, then with drug) were statistically compared using the Mann-Whitney U test (same reference as above), and the mean as well as the extreme values of the recorded numbers were established (Table 1, table line 5).

\subsection{Ants' Tactile Sensation (Presumed 'Pain Sensation') (6)}

It was tempted to assess this physiological trait by setting ants in an experimental apparatus made of a small tray $(15 \mathrm{~cm} \times 7 \mathrm{~cm} \times 4.5 \mathrm{~cm})$ into which a piece $(3 \mathrm{~cm} \times 11 \mathrm{~cm})$ of rough emery paper (number 280) was duly folded $(11 \mathrm{~cm}: 2 \mathrm{~cm}+7 \mathrm{~cm}+2 \mathrm{~cm})$ and tied to the bottom and the border of the tray, so dividing the tray in three zones: a small initial smooth zone $(3 \mathrm{~cm}$ long), a zone $(3 \mathrm{~cm}$ long) on which ants' walking should be uncomfortable, and a large smooth zone $(9 \mathrm{~cm}$ long) for inciting the ants crossing the uncomfortable zone. Two such apparatus were used, one for each used colony. The ants were tested before they consumed fluoxetine, then five days after they had continuously received that drug. Each time, 12 ants were set, all together, at the same time, in the small initial zone. The ants present in each of the three zones of the apparatus were counted after $0,2,4,6,8,10 \mathrm{~min}$, and the linear as well as the angular speed of 12 ants for each two tested colonies (so $\mathrm{n}=24$ ) moving on the rough paper were assessed using the method briefly explained in point 3.3 (Figure 1D; Table 2, table line 1). The numbers of ants obtained for ants having consumed fluoxetine were statistically compared to those previously obtained for ants of the same colonies having never ingested that drug, using the non parametric Wilcoxon test (Siegel \& Castellan, 1989 ), while the linear and angular speed of such ants were statistically compared using the non parametric $\chi^{2}$ test (same reference as above).

\subsection{An Ants' Cognitive Ability Requiring No Memory (7)}

This ability was assessed on ants of the two used nests first while these nests did not received fluoxetine, then seven days after they had continuously fluoxetine in their liquid food. The assessment was made using an adequate experimental apparatus schematically presented in the figure 3 of Cammaerts et al. (2014b) and here shown in Figure $1 \mathrm{E}$. This apparatus consisted in a small tray $(15 \mathrm{~cm} \times 7 \mathrm{~cm} \times 4.5 \mathrm{~cm})$ inside of which two pieces of white extra strong paper (Steinbach ${ }^{\circledR}, 12 \mathrm{~cm} \times 4.5 \mathrm{~cm}$ ), duly twice folded, were inserted in order to create a way with four chicanes between a narrow (too narrow for 15 ants) initial space (initial loggia) and a larger area (free loggia). Two such experimental apparatus were built and used, each one, for one of the two nests. Each time, for each nest and each feeding situation, 15 ants were collected from their colony and set all together, at the same time, in the initial loggia of the apparatus, and those located in this loggia as well as in the free loggia were counted after 0,5 , 10, 15 and $20 \mathrm{~min}$ (Table 2, table line 2). The numbers obtained for ants consuming fluoxetine were statistically compared to those previously obtained for ants having never received this substance using the non parametric Wilcoxon test (Siegel \& Castellan, 1989). 
Table 2. Effect of fluoxetine on five other ants' physiological traits

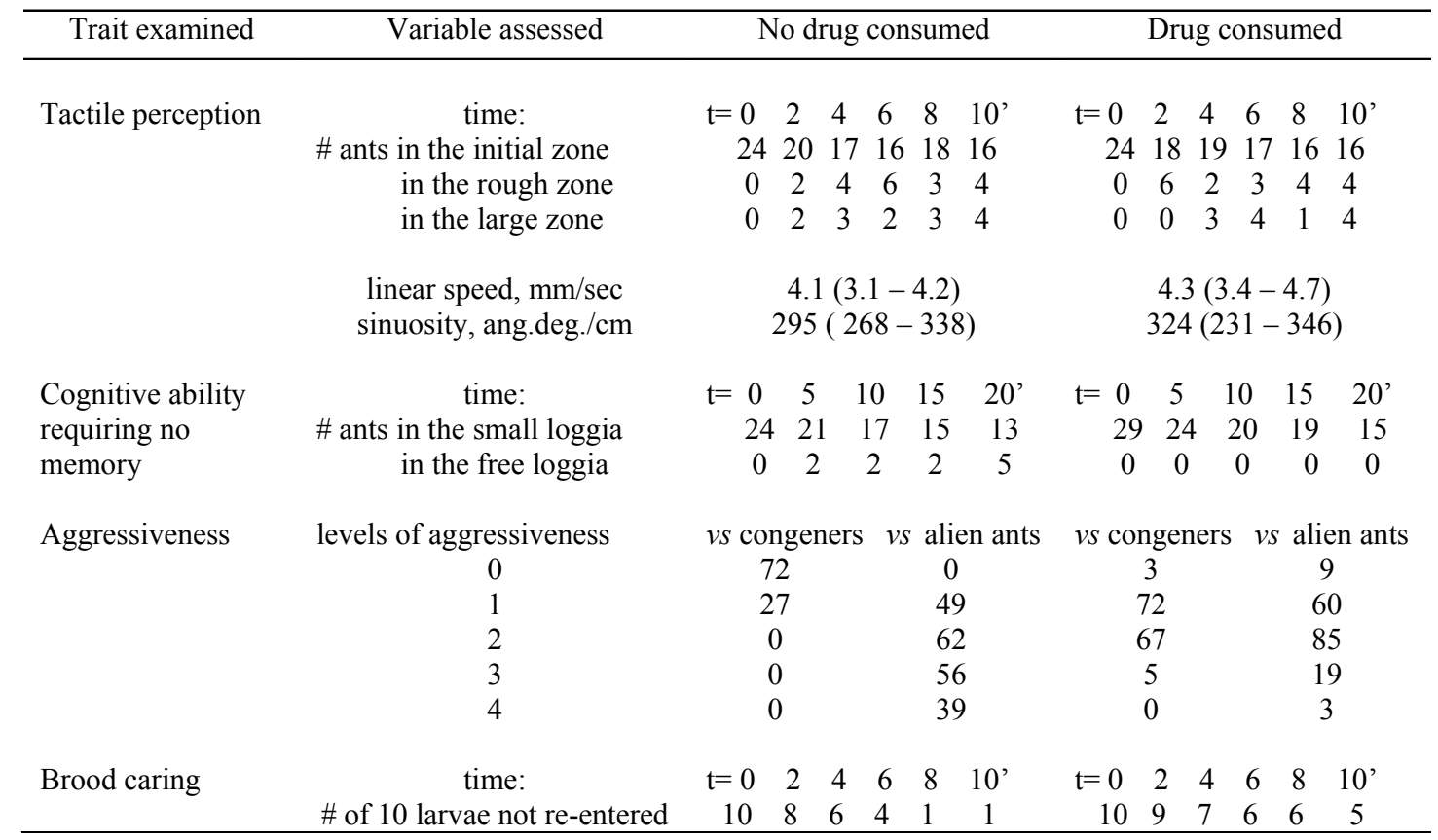

Fluoxetine appeared to have no effect on the ants' tactile perception (they went on having difficulties in crossing a rough bottom), but to affect their cognitive ability (fewer ants reached the free zone, through chicanes), their aggressiveness towards congeners (which was increased) and towards alien ants (which was decreased), as well as their brood caring behavior (which became of poor quality).

\subsection{Ants'Aggressiveness Towards Congeners or Alien Workers $(8,9)$}

This trait was quantified before the ants consumed fluoxetine, then eight days after they had continuously consumed that drug. Ants' potential aggressiveness towards nestmates as well as expected aggressiveness towards alien workers (i.e. belonging to another colony) was assessed in the course of dyadic encounters of five ants of each of the two used colonies, the encountering being conducted in a small glass (base diameter $=3 \mathrm{~cm}$, top diameter $=4 \mathrm{~cm}$, height $=5$ $\mathrm{cm}$ ), the borders of which had been slightly covered with talc. Each time (in total ten encounters with nestmates and ten encounters with alien workers, each time before then under fluoxetine consumption), the ant of the presently used colony was observed for 3 minutes and its meetings with the other ant was characterized by the numbers of times it did nothing (level 0 of aggressiveness), it touched the other ant with its antennae (level 1), it opened its mandibles in front of the other ant (level 2; Figure 1F), it gripped and/or pulled the other ant (level 3), and it tried to sting or stung the other ant (level 4). The numbers recorded for each two used colonies were added (Table 2, table line 3), and the results obtained for ants consuming fluoxetine were compared to those obtained for ants having never consumed that drug, using the non parametric $\chi^{2}$ test (Siegel \& Castellan, 1989).

\subsection{Ants' Caring Behavior (10)}

This trait was examined, for the two used colonies, before the ants consumed fluoxetine, then ten days after they had consumed that drug. Each time, a few larva were removed from the inside of the nest and deposited in front of the nest tube entrance. Five of them were carefully observed, as well as the ants' behavior in front of the larva (Figure $1 \mathrm{G}$ ). The numbers of these five larva still remaining out of the nest were counted after $0,2,4,6,8,10$ minutes, and the numbers recorded for each two colonies were added (Table 2, table line 4). The results obtained for ants consuming fluoxetine were compared to those similarly obtained for ants having never consumed that drug using the non parametric Wilcoxon test (Siegel \& Castellan, 1989).

\subsection{Ants' Visual Perception (11)}

For examining this sensorial ability, ants from each colony were trained with their own training apparatus and then tested using another similar outfit so that, again, each colony had its own test apparatus. The apparatus consisted of a glass slide $(2.6 \mathrm{~cm} \mathrm{X} 7.6 \mathrm{~cm})$ with a cube $(2 \mathrm{~cm} \mathrm{X} 2 \mathrm{~cm} \mathrm{X} 2 \mathrm{~cm})$ made of extra strong white paper (Steinbach $\left.{ }^{\circledR}\right)$ placed at an end. On one face of the cube was a blue square $(1.5 \mathrm{~cm} \mathrm{x} 1.5 \mathrm{~cm})$ and on the opposite face a yellow identical square. The cube was positioned on the glass slide so that the blue cue appeared to the left and the yellow 
cue to the right of the glass slide. The squared cues were cut from strong colored paper (Canson ${ }^{\circledR}$ ) the colors of which had previously been analyzed for their wavelengths reflection (Cammaerts, 2007, Cammaerts \& Cammaerts, 2009). During training, a T. molitor larvae cut in two pieces was tied to the end of the glass slide where there was no cube, so at $4 \mathrm{~cm}$ from the cube (Figure 1H). In this way, the reward was located $4 \mathrm{~cm}$ to the right of the blue visual cue, as well as $4 \mathrm{~cm}$ to the left of the yellow visual cue. During the tests, no meat was placed on the apparatus.

Four tests were performed six days, as well as nine days, after the ants were exposed to (and so could see) the adequate apparatus on their foraging area, the apparatus being provided with a cube free of any colored cues (first test), or a cube with a blue square (second test), or a cube with a yellow square (third test), or a cube with a blue and a yellow cues (fourth test). Each time, the ants present on the glass slide were counted 10 times, for each of the two colonies, and the mean value of the 20 counts was calculated (Table 3 ). The four kinds of counts were compared to one another using the non parametric test of Wilcoxon (Siegel \& Castellan, 1989). If the ants coming onto the glass slide in the presence of one, or the other, or the two colored cues were more numerous than those coming in the presence of a cube free of any cue, then the ants had been able to visually perceive the colored cues (Cammaerts $\&$ Rachidi, 2009, Cammaerts et al., 2011).

\subsection{Ants' Olfactory Perception (12)}

For examining this sensorial ability, ants from each two colonies were trained by way of an own experimental apparatus. Afterward they were tested using another, similar apparatus, each colony having also its own test apparatus. The apparatus consisted of a piece of extra strong white paper (Steinbach ${ }^{\circledR}, 12 \mathrm{~cm} X 6 \mathrm{~cm}$ ) orthogonally folded lengthwise to present a horizontal and a vertical part. A small glass tube (length: $7 \mathrm{~cm}$; diameter: $1 \mathrm{~cm}$ ) was inserted into a hole (diameter: $1.2 \mathrm{~cm}$ ) cut in the middle of the vertical part very close to the base. The glass tube was placed in the foraging area with the opening in the middle of the apparatus. A schema of such an apparatus is given in Cammaerts and Rachidi (2009). During training, the glass tube was filled with sugared water (the reward) and closed with a cotton plug, while pieces of thyme and pieces of estragon were deposited on a glass slide cover slip $(2.2 \mathrm{~cm} \mathrm{x}$ $2.2 \mathrm{~cm}$ ) located respectively on the left and on the right horizontal ends of the experimental apparatus. In this way, the reward (sugared water, renewed when necessary) was located $4 \mathrm{~cm}$ to the right of the thyme and $4 \mathrm{~cm}$ to the left of the estragon. Another glass slide cover slip was located in the middle of the apparatus in front of the opening of the sugared water glass tube. The experimental apparatus used for testing was free of odorous plants, or provided with thyme, or with estragon, or with both cues depending on the experiments, and the glass tube was empty (i.e., no reward was given during tests), but closed with a cotton plug to prevent entry.

Four tests were so performed six days, as well as nine days, after the ants were exposed to (and so could perceive) the two odors, together with their sugar food, on their foraging area, using the four here above cited experimental designs. During each series of tests, the ants were counted 10 times, for each of the two used colonies, on the entire area of the apparatus (free of any plants), or on the left-half area of the apparatus (provided with pieces of thyme), or on the right-half area of the apparatus (provided with pieces of estragon), or on the entire area of the apparatus (provided with pieces of the two odorous plants). Each time, the mean value of the 20 counts was calculated (Table 3 ), while the four kinds of counts were compared to one another using the non parametric test of Wilcoxon (Siegel \& Castellan, 1989). If the ants coming onto the apparatus in the presence of one, or the other, or the two olfactory cues were more numerous than those coming in the absence of such cue, then the ants had been able to olfactory perceive the odorous cues (Cammaerts \& Rachidi, 2009, Cammaerts et al., 2011).

Table 3. Visual and olfactory perception of ants under fluoxetine consumption

\begin{tabular}{ccccc}
\hline Visual perception & no cue & blue cue & yellow cue & the two cues \\
\hline after 6 days & 0.25 & 1.80 & 1.00 & 1.20 \\
after 9 days & 0.40 & 0.85 & 1.10 & 0.85
\end{tabular}

\begin{tabular}{ccccc} 
Olfactory perception & no odor & thyme & estragon & the two odors \\
\hline after 6 days & 0.60 & 0.70 & 0.65 & 1.00 \\
after 9 days & 0.30 & 0.25 & 0.35 & 0.55 \\
\hline
\end{tabular}

After having been in presence of two visual cues and two odorous ones, for six, then nine days, ants were tested in front of each of these cues. They reacted to the visual cues but not significantly to the olfactory ones. More experimental and statistical details are given in the text. 


\subsection{Ants' Visual and Olfactory Operant Conditioning Ability and Memory $(13,14,15,16)$}

Briefly, at a given time, either a green hollow cube or pieces of dried shallots were set above the pieces of $T$. molitor larva, this time tied to the supporting piece of glass. The ants so underwent, either visual or olfactory operant conditioning. Each time, tests were performed, in the course of time, while the ants were expected acquiring conditioning, then, after having removed the green cube or the pieces of shallots, while the ants were expected to partly lose their conditioning.

In detail, ants were collectively visually trained to a hollow green cube constructed of strong paper (Canson $\left.{ }^{\circledR}\right)$ according to the instructions given in Cammaerts and Nemeghaire (2012) and set over the meat food which served as a reward. The color has been analyzed to determine its wavelengths reflection (Cammaerts, 2007). Only the ceiling of each cube was filled, this allowing ants entering the cube. Choosing the green cube was considered as giving the 'correct' choice when ants were tested as explained below. The ants were olfactory conditioned by setting pieces of dried shallots aside the tied pieces of T. molitor larva. Choosing the pieces of shallots was considered as giving the 'correct' choice when ants were tested as explained below.

Table 4. Effects of fluoxetine an ants' visual and olfactory learning and memory

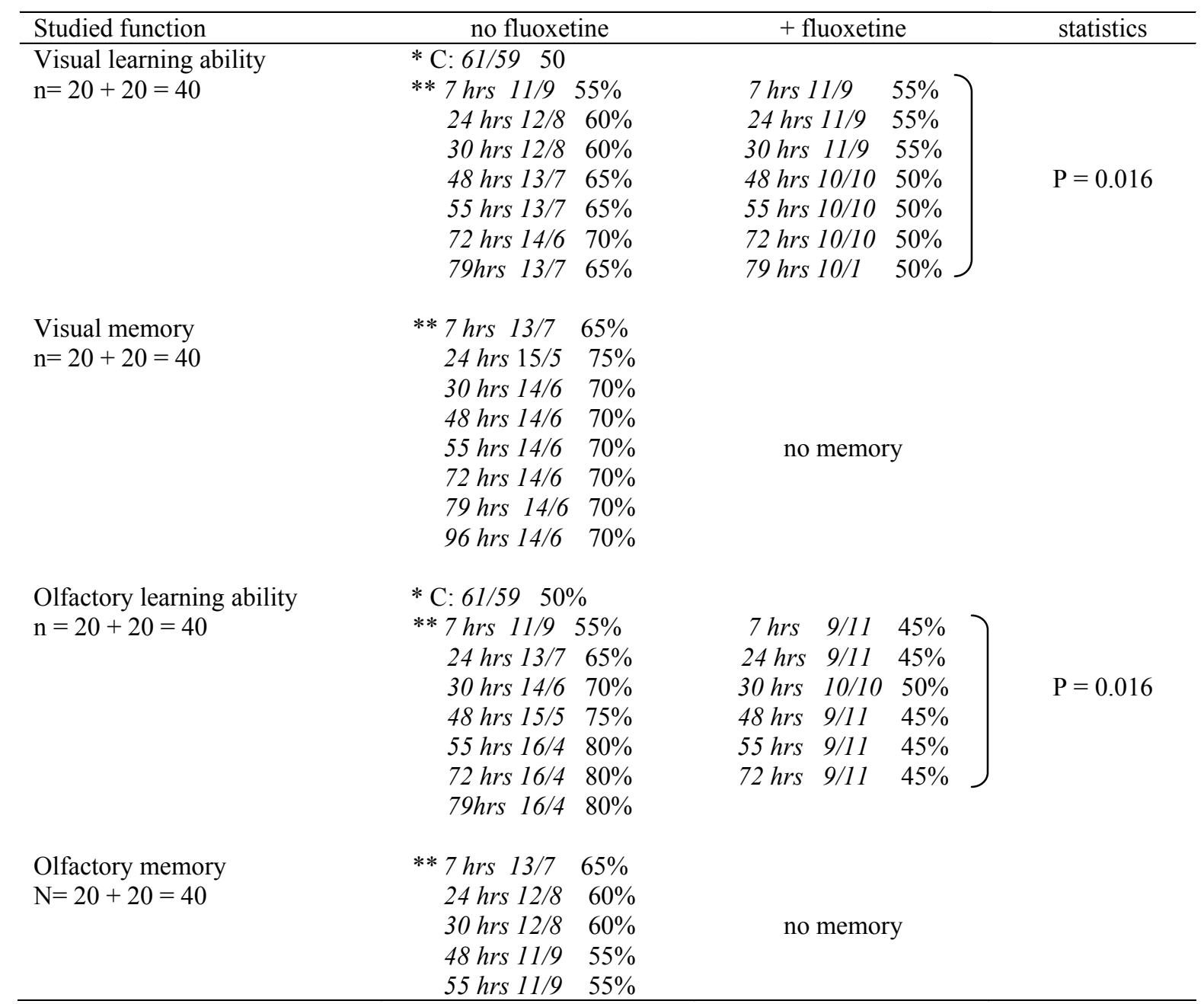

Ants were trained to a green hollow cube or to pieces of shallots set above or aside the meat food. Then, tests were made in the course of time: the numbers of ants giving the correct and the wrong response were counted, and the percentage of correct responses for the ant population was determined. The percentages obtained for ants consuming fluoxetine were compared to those previously obtained (by * Cammaerts et al., 2011, ** Cammaerts, Gosset, Rachidi, 2014b) for ants having never consumed this drug, using the non parametric Wilcoxon test (Siegel and Castellan, 1989). These results are graphically presented in Figure 2. 
Ants were individually tested in a Y-shaped apparatus (Figure 1I) constructed of strong white paper according to the instructions given in Cammaerts et al. (2011), and set in a small tray $(30 \mathrm{~cm} \times 15 \mathrm{~cm} \times 4 \mathrm{~cm})$, apart from the experimental colony's tray. Each colony had its own testing device. The apparatus had its own bottom and the sides were slightly covered with talc to prevent the ants from escaping. In the Y-apparatus, the ants deposited no trail since they were not rewarded. However, they could utilize other chemical secretions as traces. As a precaution, the floor of each Y-apparatus was changed between tests. The Y-apparatus was provided with either a green cube, or pieces of dried shallots, in one or the other branch. Half of the tests were conducted with the cube, or the odorous plant, in the left branch and the other half with the cube, or the odorous plant, in the right branch of the Y maze, and this was randomly chosen. Control experiments had previously been made on never conditioned ants and on trained ants of colonies having never received fluoxetine (Table 4:* from Cammaerts et al., 2011:** from Cammaerts et al., 2014b). This must be done because, once an animal is conditioned to a given stimulus, it becomes no longer naïve for such an experiment. It was so impossible to perform, on the same ants, conditioning without then with fluoxetine in the ants' food. The only solution was thus to use previous results obtained in the course of identical experiments made on very similar colonies never fed with any drug.

To conduct a test on a colony, 10 workers - randomly chosen from the workers of that colony - were transferred one by one onto the area at the entrance of the Y-apparatus. Each transferred ant was observed until it turned either to the left or to the right in the Y-tube, and its choice was recorded. Only the first choice of the ant was recorded and this only when the ant was beyond a pencil drawn thin line indicating the entrance of a branch (Figure 1I). Afterwards, the ant was removed and transferred into a polyacetate cup, in which the border was covered with talc, until 10 ants were so tested, this avoiding testing the same ant twice. All the tested ants were then placed back on their foraging area. For each experiment, the numbers of ants, among $n=10+10=20$, which turned towards the "correct" green cube or pieces of shallots, or went to the "wrong" empty branch of the Y were recorded. The percentage of correct responses for the tested ant population was so established (Table 4, Figure 2). The results obtained for ants that have consumed fluoxetine were compared to previous results obtained for ants that had never consumed that substance, using the non parametric Wilcoxon test (Siegel \& Castellan, 1989). The value of $\mathrm{N}, \mathrm{T}$, and $\mathrm{P}$, according to the nomenclature given in the here above reference, are defined in the results section.

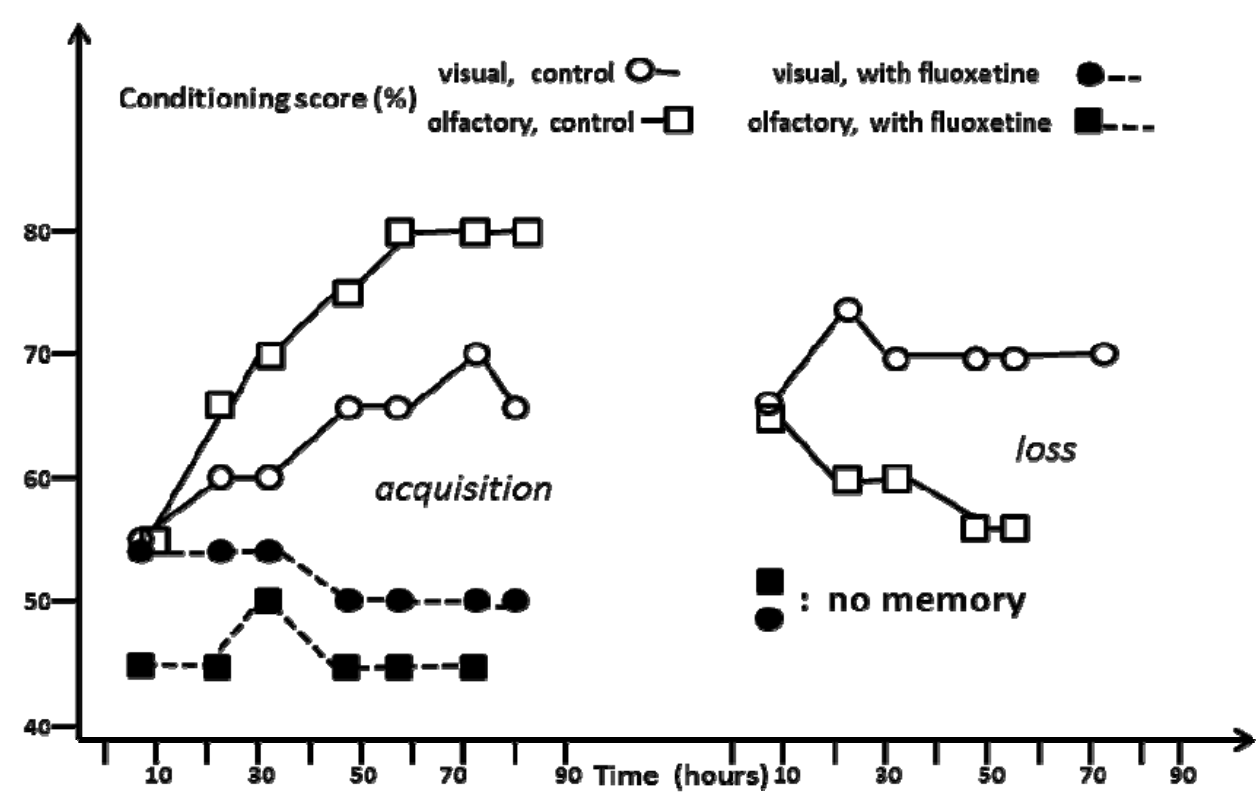

Figure 2. Ants' conditioning to a visual and an odorous cue

Numerical results and statistical evaluation are given in Table 4. The legend is identical to that of this table. Since under fluoxetine consumption, ants could not acquire conditioning, their memory could not be assessed (they behaved just as if they had no visual and no olfactory memory). 


\subsection{Ants' Habituation to the Drug Consumption (17)}

Fourteen days after the ants had continuously consumed fluoxetine, their linear and angular speed, as well as their orientation towards an isolated worker's head, were assessed (Table 5, table line 1). The results were compared to the control ones and to those obtained after two days of drug consumption using the non parametric $\chi^{2}$ test (Siegel \& Castellan, 1989).

Table 5. Habituation to, and dependence on, fluoxetine consumption, as well as decrease in the course of time of the effects of this drug

\begin{tabular}{|c|c|c|c|c|c|}
\hline \multirow{4}{*}{$\begin{array}{l}\text { Effect studied } \\
\text { habituation }\end{array}$} & Variable assessed & \multicolumn{4}{|c|}{ Numerical results } \\
\hline & linear speed $(\mathrm{mm} / \mathrm{sec})$ & \multirow{2}{*}{\multicolumn{2}{|c|}{$\begin{array}{l}12.3(10.6-13.4) \\
176(168-194)\end{array}$}} & \multirow{2}{*}{\multicolumn{2}{|c|}{$\begin{array}{l}\text { vs control: } \mathrm{P}<0.001 ; \text { vs two days: NS } \\
\text { vs control: } \mathrm{P}<0.001 ; \text { ss two days: NS }\end{array}$}} \\
\hline & angular speed (ang.deg/cm) & & & & \\
\hline & $\begin{array}{l}\text { orientation towards an alarm } \\
\text { signal (ang.deg.) }\end{array}$ & \multicolumn{2}{|c|}{$73.9(62.2-93.1)$} & \multicolumn{2}{|c|}{ vs control: $\mathrm{P}<0.001 ;$ vs two days: NS } \\
\hline $\begin{array}{l}\text { dependence } \\
\text { (12 counts) }\end{array}$ & $\begin{array}{l}\text { choices between sugar water } \\
\text { and sugar water + fluoxetine }\end{array}$ & \multicolumn{4}{|c|}{$\begin{array}{l}\text { nest } 1: 15 \text { ants and } 7 \text { ants } \rightarrow 68.18 \% \text { and } 31.81 \% \\
\text { nest } 2: 36 \text { ants } \text { and } 25 \text { ants } \rightarrow 59.01 \text { and } 40.98 \%\end{array}$} \\
\hline \multirow{11}{*}{$\begin{array}{l}\text { duration of } \\
\text { effects }\end{array}$} & angular speed (ang. deg./cm) & Tohrs & 182( & $151-193)$ & $86.7(74.0$ - 97.4) \\
\hline & followed by orientation towards & T 4hrs & 168( & $151-212)$ & $83.8(76.1-930)$ \\
\hline & an alarm signal (ang.deg.) & $T 8 h r s$ & 157( & $139-166)$ & $749(62.6$ - 98.4) \\
\hline & & $T 12.5 \mathrm{hrs}$ & 148( & $131-168)$ & $70.6(673-81.7)$ \\
\hline & control: 113 and 34.5 & $T 20.5 \mathrm{hrs}$ & 140( & $114-147)$ & $67.3(60.4-92.1)$ \\
\hline & & $T 24.5 \mathrm{hrs}$ & 135( & $113-151)$ & $63.9(54.9-78.5)$ \\
\hline & & $T 30.5 \mathrm{hrs}$ & 130( & $114-148)$ & $60.6(42.9-78.2)$ \\
\hline & & T 37hrs & 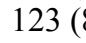 & $87-149)$ & $49.5(28.2-57.3)$ \\
\hline & & $T 45 \mathrm{hrs}$ & 119( & $116-136)$ & $46.5(40.0-58.5)$ \\
\hline & & T 50hrs & & & $41.0(33.6-51.3)$ \\
\hline & & T 58hrs & & & $34.9(23.6-50.4)$ \\
\hline
\end{tabular}

Experimental methods and more statistical analysis are given in the text. Fluoxetine leaded to no habituation, and to no dependence. Its effects on locomotion (and so general activity) ended in about two days, and on olfaction and precision of reaction in about two and a half days.

\subsection{Ants' Dependence on the Drug Consumption (18)}

After the ants had continuously consumed fluoxetine during five days, an experiment was performed for examining if they acquired some dependence on the consumed drug. Fifteen ants of each two used colonies were transferred into a small tray $(15 \mathrm{~cm} \times 7 \mathrm{~cm} \times 5 \mathrm{~cm})$, the borders of which had been covered with talc and in which two tubes $(\mathrm{h}=2.5 \mathrm{~cm}$, diam. $=0.5 \mathrm{~cm})$ were laid, one containing sugar water, the other sugar water and fluoxetine (at the concentration 1/1,000), each tube being plugged with cotton. In one of the trays, the tube containing the drug was located on the right; in the other tray, it was located on the left. Photographs of such an experimental design can be seen in Cammaerts et al., 2014 a, b, and in Cammaerts \& Cammaerts R., 2014. The ants drinking each liquid food were counted 12 times, the mean values being then established for each kind of food (Tables 5 , table line 2). They were statistically compared to the values expected if ants randomly went drinking each kind of food, using the non parametric goodness of fit $\chi^{2}$ test (Siegel \& castellan, 1989).

\subsection{Decrease of the Effects of the Drug, After Its Consumption Ended (19)}

Three weeks after that the ants had continuously consumed fluoxetine, the liquid food containing the drug was removed from the ants' tray and replaced by sugar water free of any drug. This change was made at a given recorded time. After that, the ants' angular speed and their orientation towards an isolated worker's head were assessed after successive given time periods (Tables 5, table line 3; Figure 3). The results revealed the decrease of the effects of the drug, on ants. Their statistical significance could be estimated via the non parametric $\chi^{2}$ test (Siegel \& Castellan, 1989). 


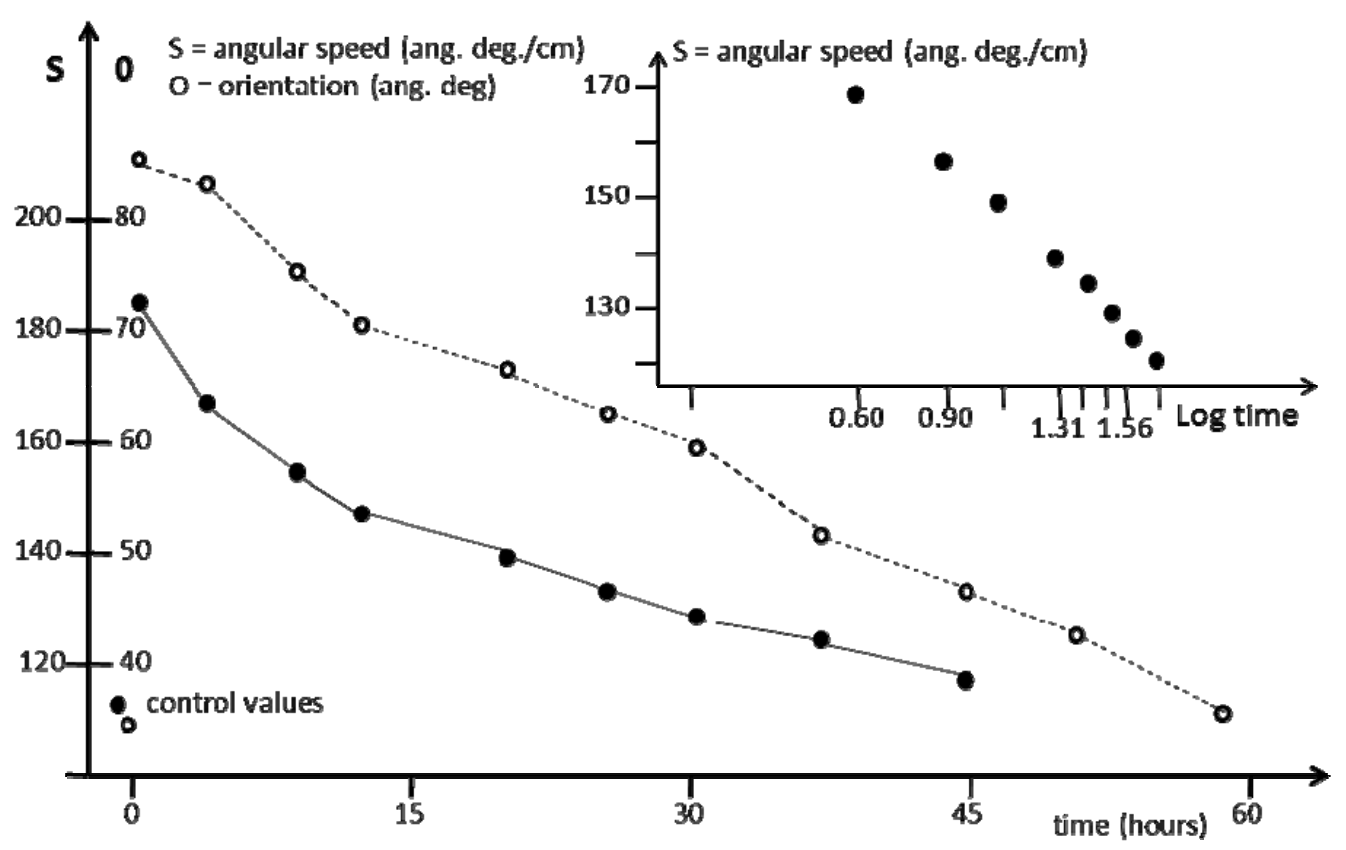

Figure 3. Decrease of the effects of fluoxetine on sinuosity (S) and on precision of reaction, in the course of time The first effect (black circles) vanished in about two days $[S=F(\log t)]$, while the second one (empty circles) ended after about two and a half days $(\mathrm{O}=\mathrm{F}$ t). Experimental and statistical details are given in the text.

\section{Results}

\subsection{Locomotion, General Activity (1)}

These traits were affected by fluoxetine consumption.

While under normal diet, ants moved rather rapidly (median $=14.9 \mathrm{~mm} / \mathrm{sec}$ ) and with a moderate sinuosity (median $=113$ ang. deg. $/ \mathrm{cm}$ ), after having consumed fluoxetine for two days, they moved more sinuously (median $=149$ ang.deg. $/ \mathrm{cm}$ ) and consequently somewhat more slowly (median $=13.1 \mathrm{~mm} / \mathrm{sec}$ ) (Figure 1A). These results were significant (Table 1, table line 1; linear speed: $\chi^{2}=8.6, \mathrm{df}=2,0.01<\mathrm{P}<0.02$; angular speed: $\left.\chi^{2}=17.58, \mathrm{df}=2, \mathrm{P}<0.001\right)$.

The ants' general activity appeared to have changed. As soon as $24 \mathrm{hrs}$ after having consumed fluoxetine, several workers seemed excited, they often turned back on their way, they presented shivering and sometimes unusual movements of the legs. In front of congeners, they stopped, as in alert, often opened their mandibles, and sometimes roughly contacted them. Few ants were observed on the food sites while many ones acted as guarding at the entrances of the nest tubes.

\subsection{Orientation Towards a Source of Alarm Pheromone (= Precision of Reaction) (2)}

Under normal diet, ants very well oriented themselves towards a punctual source of alarm pheromone (median = 34.5 ang. deg.). After having consumed fluoxetine for two days, they badly did so (median $=69.4$ ang. deg.): they moved towards a wrong direction, or they went near then over the alarm signal without succeeding in approaching it as they usually do. Such a result was significant (Table 1 , table line $2 ; \chi^{2}=11.63, \mathrm{df}=2,0.001<\mathrm{P}<0.01$ ).

\subsection{Trail Following Behavior (= Response to Pheromones) (3)}

On a blank circumference, either ants under normal diet or those consuming fluoxetine did not move along the traced line free of pheromone. Ants under normal diet very well followed a circular trail imbibed with one poison gland extract $\left(\right.$ median $=12.0$ arcs of $10^{\circ}$ ), a value similar to previous obtained ones (Cammaerts et al., $2014 \mathrm{a}, \mathrm{b}$; Cammaerts \& Cammaerts R., 2014). After having consumed fluoxetine for three days, ants very badly followed such a circular trail (median $=3.5 \mathrm{arcs}$ ). When reaching the trail, they seemed to have difficulties in perceiving the pheromone; they often followed it along only a few arcs, and sometimes only crossed the trail without following it. Sometimes, they stopped, turned, and moved away from the trail (Figure 1B). Such a result was highly significant (Table 1, table line $3 ; \chi^{2}=38.63, \mathrm{df}=2, \mathrm{P}<0.001$ ). 


\section{4 "Audacity" (4)}

Such a trait (assessed through the number of ants coming onto a test apparatus, Figure 1C) was only slightly and not statistically affected by fluoxetine consumption (1.62 vs 1.35 , Table 1 , table line $4 ; \mathrm{U}=136, \mathrm{Z}=-1.72, \mathrm{P}=$ 0.0858). Once more, during this experiment, ants were seen stopping in front of congeners and opening then their mandibles.

\subsection{Food Consumption (5)}

This trait was affected by fluoxetine consumption. Under normal diet, meanly 2.2 ants were present on the meat site, while after having consumed fluoxetine for three days, only meanly 0.46 ants were observed on that site. Such a result was statistically significant (Table 1 , table line $5 ; \mathrm{U}=24, \mathrm{Z}=4.75, \mathrm{P}=0.000002$ ).

\subsection{Tactile Sensation (Pain Perception) (6)}

This trait was not affected by fluoxetine consumption (Table 2 ; line 1).

The numbers of ants under fluoxetine consumption remaining in the initial zone, the numbers of ants crossing the rough zone, and of ants reaching the large zone were similar and statistically not different from the corresponding numbers of ants having never consumed fluoxetine. Each time, only few ants could cross the rough zone. The statistical results were: initial zone: $\mathrm{N}=4, \mathrm{~T}=-6, \mathrm{P}=0.438$; rough zone: $\mathrm{N}=4, \mathrm{~T}=+7, \mathrm{P}=0.313$; large zone: $\mathrm{N}$ $=3, \mathrm{~T}=-4, \mathrm{P}=0.375$. Also, the locomotion of ants consuming fluoxetine, on the rough bottom, was similar and statistically not different from that of ants having never consumed fluoxetine, on the same substrate. Each time, ants moved very slowly, cautiously, presenting a very large sinuosity, and appearing to be uncomfortable (Figure 1D). The control and test median values, and the statistical results were the following ones: linear speed: 4.1 vs 4.3 $\mathrm{mm} / \mathrm{sec}, \chi^{2}=0, \mathrm{df}=1, \mathrm{P}=1.00$; angular speed: 295 vs 324 ang. deg. $/ \mathrm{cm}, \chi^{2}=0.11, \mathrm{df}=1, \mathrm{P} \approx 0.95$. Thus, fluoxetine did not decrease the ants' potential "pain" perception, or at least did not affect the tactile sensation when walking.

\subsection{Cognitive Ability Requiring No Memory (7)}

This trait assessed before ants consumed fluoxetine, then seven days after they had continuously consumed that drug, appeared to be affected by fluoxetine consumption (Table 2, table line 2). Indeed, among the 30 ants set in the initial small loggia, under normal diet 13 ants were still there after 20 min. while five ones were moving in the large free area (Figure 1E), and under fluoxetine consumption, 15 ants were still in the initial loggia while no any ant could reach the free large loggia. This result was significant: initial $\operatorname{loggia}: \mathrm{N}=5, \mathrm{~T}=15, \mathrm{P}=0.031$; free loggia: $\mathrm{N}=4, \mathrm{~T}=10, \mathrm{P}=0.063$.

\subsection{Aggressiveness Against Nestmates and Alien Workers $(8,9)$}

These two traits appeared to be somewhat affected by fluoxetine consumption (Table 2, table line 3 ).

Concerning potential aggressiveness towards nestmates, ants under normal diet never aggressed their congeners during the ten artificial dyadic encounters, while ants consuming fluoxetine were rather aggressive in identical circumstances (Figure 1F). Indeed, these last ants presented in total 67 gripping behavior and 5 stinging ones. This result was statistically significant $\left(\chi^{2}=163.6, \mathrm{df}=2, \mathrm{P}<0.001\right)$.

Concerning expected aggressiveness towards alien ants of the same species, ants under normal diet immediately (without delay) attacked the alien ant in the course of each of the ten artificial dyadic encounters performed. In total, 62 mandibles openings, 56 gripping behaviors, and 39 stinging ones were observed. On the contrary, ants under fluoxetine consumption experimented in identical circumstances differed in time their aggressive behavior, sometimes moved away from the alien ant, and exhibited in total 69 non aggressive contacts, 85 mandibles openings, 19 gripping behaviors, and only 3 stinging ones. This result was statistically significant $\left(\chi^{2}=50.46, \mathrm{df}=\right.$ $2, \mathrm{P}<0.001)$. In fact, under fluoxetine consumption, the ants' behavior in front of an alien worker varied from escaping to slight aggressiveness.

Thus, under fluoxetine behavior, ants became somewhat aggressive towards nestmates, but less aggressive towards alien workers. However, they were still a little (and largely less than under normal diet) more aggressive against alien ants than against congeners $\left(\chi^{2}=10.61, \mathrm{df}=2,0.001<\mathrm{P}<0.01\right)$.

\subsection{Caring Behavior (10)}

This trait was affected by fluoxetine consumption (Table 2, table line 4).

Under normal diet, all the five larva of nest 1 removed from their nest were re-entered by workers in six minutes, and four larva among five were re-entered, in ten minutes, by workers of nest 2 (Figure 1G). 
Under fluoxetine consumption, after 10 minutes, two larva among five for nest 1, and three larva among five for nest 2 were still outside of the nest tubes, at about one $\mathrm{cm}$ of the nest entrances. Such a difference between the two experiments was statistically significant $(\mathrm{N}=5, \mathrm{~T}=15, \mathrm{P}=0.031)$.

During the last experiment, the ants' behavior was carefully observed. In general, when approaching a larvae, an ant under fluoxetine consumption did not take the larvae with its mandibles, or took it then dropped it, or took the larvae but moved onto the foraging area instead of towards a nest entrance, or moved towards the entrance, holding the larvae, but failed in correctly entering the nest. Finally, with the help of several workers, the larva was re-entered, in successive right and wrong steps. Also, several nymphs present in nest 1 appeared to have been eaten by workers. Some eluvia of nymphs were also present in nest 1 while under normal diet such eluvia are not observed inside a nest (Cammaerts \& Gosset, 2014b).

So, brood caring was of poor quality in ant population having fluoxetine in their liquid sugared food.

\subsection{Visual and Olfactory Perception $(11,12)$}

Myrmica sabuleti workers are known for having a rather good visual perception (at least color perception (Cammaerts, 2007) and an excellent olfactory perception, using primarily odors for traveling (Cammaerts \& Rachidi, 2009).

Results of the tests performed six, then nine days after ants, under fluoxetine consumption, have had the possibility to perceive two colors (blue and yellow) and two odors (thyme and estragon), were perfectly in agreement (Table 3).

As for the ants' visual perception (Figure 1H), the number of ants reacting to the blue cue as well as to the yellow one was statistically higher than those of ants reacting to no color at all (first test: blue: $\mathrm{N}=10, \mathrm{~T}=55, \mathrm{P}=0.001$; yellow: $\mathrm{N}=9, \mathrm{~T}=45, \mathrm{P}=0.002$; second test: blue: $\mathrm{N}=7, \mathrm{~T}=28, \mathrm{P}=0.008$; yellow: $\mathrm{N}=10, \mathrm{~T}=55, \mathrm{P}=0.001$ ). The ants better reacted to the blue cue during the first test and to the yellow cue during the second test because the experimental apparatus was differently oriented after the first test, the yellow cue fronting then the nest entrances. Of course, the ants were also more numerous in the presence of the two cues than in the absence of color: first test: $\mathrm{N}=10, \mathrm{~T}=55, \mathrm{P}=0.001$; second test: $\mathrm{N}=9, \mathrm{~T}=36, \mathrm{P}=0.064$ ). Moreover, for each of the two tests, the number of ants reacting to the two cues was lower than the sum of those of ants reacting to each of the two cues, and approached each of these two last numbers (first test: $1.20<1.80+1.00$; second test: $0.85<1.10+0.85$ ). This allowed concluding that same ants have memorized, so clearly perceived, each of the two cues.

As for the ants' olfactory perception, the number of ants reacting to thyme, to estragon, or to the two odors was not statistically different from that of ants reacting in the absence of any odor. The statistical results were the following ones: first test: thyme: $\mathrm{N}=2$, NS; estragon: $\mathrm{N}=3$, NS; the two odors: $\mathrm{N}=9, \mathrm{~T}=29, \mathrm{P}=0.248$; second test: thyme: $\mathrm{N}=5, \mathrm{~T}=-4, \mathrm{P}>0.50$; estragon: $\mathrm{N}=6, \mathrm{~T}=5, \mathrm{P}>0.50$; the two odors: $\mathrm{N}=8, \mathrm{~T}=7, \mathrm{P}>0.53$ ). Moreover, for each of the two tests, the ants reacting in the presence of the two odors were more numerous than those reacting to each of these odors and approached the sum of the two last numbers. More precisely, for the first test, $1.00>0.70$, $1.00>0.65$ and $1.00 \approx 0.70+0.65$, while for the second test, $0.55>0.25,0.55>0.35$ and $0.55 \approx 0.25+0.35$. This allowed to presume that ants have remembered (so clearly perceived) only one of the two odors, and not the two ones. Such a lack of (or at least some deficiency in) olfactory perception is not at all usual for the studied species $M$. sabuleti. Such a physiological effect may explain several ethological ones such as aggressiveness, lower response to pheromones, brood caring of poor quality.

\subsection{Visual and Olfactory Learning and Memory $(13,14,15,16)$}

Even after 79 hours of training, ants under fluoxetine consumption could not acquire visual conditioning (Table 4, upper part; Figure 2, black circles). Tested ants often came towards the green hollow cube, then stopped, opened their mandibles, and went away from the cube. Only half the tested ants moved under the green cube (Figure 1I). Fluoxetine so impacted the insects' visual conditioning capability.

In the same way, and even to a slightly stronger extent, ants under fluoxetine consumption could not acquire olfactory conditioning (Table 4, lower part; Figure 2, black squares). They behaved just as if they really did not know at all the presented odor. This confirmed the lack of olfactory perception, and the incapability of ants to acquire conditioning (pieces of shallots could have been seen), under fluoxetine consumption.

\subsection{Habituation to Fluoxetine Consumption (17)}

Two assessments were made for examining such a habituation (Table 5, upper part).

The ants' locomotion was assessed two days, and then 14 days after the ants had continuously consumed fluoxetine. The impact of the drug on the ants' sinuosity of movement (and consequently on linear speed) still remained after 14 days of drug consumption. Indeed, the obtained median values were $176 \mathrm{ang}$. deg./cm (12.3 
$\mathrm{mm} / \mathrm{sec})$ after 14 days, while after two days they equaled $149 \mathrm{ang}$. deg/cm (13.1 mm:sec), and during the control experiment, $113 \mathrm{ang}$. deg./cm $(14.9 \mathrm{~mm} / \mathrm{sec})$. Such a result was statistically significant: 14 days vs two days: linear speed: $\chi^{2}=2.74, \mathrm{df}=2,0.20<\mathrm{P}<0.30$; angular speed: $\chi^{2}=1.13, \mathrm{df}=1,0.20<\mathrm{P}<0.30 ; 14$ days $v s$ control: linear speed: $\chi^{2}=17.33, \mathrm{df}=2, \mathrm{P}<0.001$; angular speed: $\chi^{2}=36.19, \mathrm{df}=1, \mathrm{P}<0.001$

The ants' orientation towards a source of alarm pheromone was assessed after two days, then after 14 days of fluoxetine consumption. The impact of the drug on the ants' precision of response remained in the course of time: the median value was 73.9 ang. deg. after 14 days while it equaled 69.9 ang. deg. after two days, and 34.5 ang. deg. during the control experiment. Such a result was statistically significant: 14 days $v s$ two days: $\chi^{2}=2.09$, df $=2$, $0.30<\mathrm{P}<0.50 ; 14$ days $v s$ control: $\chi^{2}=16.53, \mathrm{df}=2, \mathrm{P}<0.001$.

We can thus conclude that individuals presented no habituation to the effects of fluoxetine, at least during the duration of the experiment (one month in total).

\subsection{Dependence on Fluoxetine Consumption (18)}

Results obtained for nest 1 and nest 2 were in agreement (Table 5, middle part). Fifteen ants of nest 1 were counted on the food free of fluoxetine while 7 ones were on food containing fluoxetine. For nest 2, the corresponding counts were 36 and 25 respectively. So, in total 51 ants were counted, during 24 counts, on the food free of fluoxetine; the mean number of ants on such a food equaled thus 2.13. In the same way, 32 ants were counted, during 24 counts, on the food containing fluoxetine; the mean number of ants choosing that food equaled thus 1.33 . These results can also be expressed in percentages: $51 / 83=61.45 \%$ ants were seen on food free of fluoxetine while $32 / 83=38.55 \%$ were seen on food containing fluoxetine. A non parametric goodness of fit $\chi^{2}$ test gave $\chi^{2}=4.35$, df $=1,0.02<\mathrm{P}<0.05$. Ants thus did not present any dependence on fluoxetine consumption, even preferring food free of that drug, this last result being not highly but yet significant.

\subsection{Decrease of Fluoxetine Effects, in the Course of Time (19)}

The drug very slowly lost its effects. The ants' behavior perfectly reflected the obtained numerical results. They moved less and less sinuously, in the course of time, being at the same time less and less aggressive towards congeners, until they moved as usual about 45 hours after they ceased to consume fluoxetine. They went on having difficulties for perceiving the presented alarm signal and for orienting themselves towards it during about 30 hours after their consumption of fluoxetine ended, then they progressively did so more easily, and finally, 58 hours after they ceased consuming fluoxetine, they behave normally. The effect of the drug on olfactory perception and precision of response lasted so a somewhat longer time period (about $2 \frac{1}{2}$ days) than its effect on the locomotion (about 2 days) (Table 5, lower part, Figure 3). However, statistically, the ants' sinuosity of movement no longer differed from the control one after $301 / 2$ hrs $\left(301 / 2\right.$ hrs: $\chi^{2}=2.89$, df $=2$, NS; 37 hrs: $\chi^{2}=0.91$, df $=2$, NS), and the ants' orientation no longer differed from the control one after $45 \mathrm{hrs}\left(45 \mathrm{hrs}: \chi^{2}=3.75\right.$, df $=2,0.10<\mathrm{P}<0.20 ; 50$ hrs: $\left.\chi^{2}=0.48, \mathrm{df}=2, \mathrm{NS}\right)$. It also appeared that the effect on olfaction and precision of reaction linearly vanished with time $(=\mathrm{t})(\mathrm{O}=0.83 \mathrm{t})$, while the effect on sinuosity (so on general activity) vanished with the logarithm of time $(S=F(\log t)$; $S$ linearly decreased with the logarithm of t: Figure 3$)$.

\section{Discussion}

Working on Myrmica sabuleti as a biological model, we found that fluoxetine changed the general activity of the ants, increasing their sinuosity of movement, decreased their precision of response and their response to pheromones, and drastically decreased their food consumption. Fluoxetine did not affect their tactile perception, but decreased their cognition. This substance also induced aggressiveness towards nestmates while reducing that towards aliens. Under fluoxetine consumption, ants less cared of their brood (and even eat nymphs), kept intact their visual perception but lost their olfactory one, and could not acquire visual or olfactory conditioning. Ants presented no habituation to, and no dependence on, fluoxetine consumption. After fluoxetine consumption ended, the effect of the drug on the ants' locomotion vanished in about two days, while that on the ants' olfaction and precision of response vanished in two and a half days.

The present work on the effects of fluoxetine on ants is in agreement with the conclusions of Sauvé (2011) and Klaper (2013): that drug affects the physiology and the behavior of animals, and may so affect any aquatic organism living in contaminated water. We think, among others, to excitation, aggressiveness, loss of olfaction, reduced food consumption, loss of remembering, these effects being rather long lasting. The potency of the here pointed out effects of fluoxetine should also be taken into account when this drug is given to humans, even if conditions of exposure (dose, duration, ...) as well as human physiology and neural processes could differ from those of ants. However, some of these effects are presently presumed for humans or known but not divulgated and really not enough considered especially during long lasting treatments (Antidépresseur, ND). A future work on 
ants will examine effects of antidepressants free of fluoxetine, for checking if these effects (somewhat reported by Brodin, Fick, Jonsson \& Klaminder, 2013 and Thomas, Joshi \& Klaper, 2012) are weaker than those of antidepressants containing fluoxetine, and if physical dependence to them occurs. Let us recall that, in the course of the present experimentation, ants never develop habituation to or dependence on fluoxetine consumption.

Punctual points of the present work should now be discussed.

We used two experimental colonies and, generally, 20 - 40 individuals for each experiment. The samples are so rather small but, in fact, not too small for ethological studies, and we used non parametric statistics for evaluating the results. Nnumerical results were in accordance with our general impression resulting from direct observations of the ants. For instance, fewer food consumed was observed every days and not only during the experiment. Aggressiveness between congeners was evident, with many widely mandibles openings; less care of the brood was obvious and, after the experimental period of two months, there was nearly no more living brood in the nests. Also, during the experiment relative to potential dependence, ants obviously avoided the drug, and one day after fluoxetine was removed from the ants' food, many ants came onto the sugar food free of the drug, indicating that they only scarcely drunk the sugar food containing fluoxetine. This allows us to suspect that if an animal, including humans, present dependence on fluoxetine consumption, it is only a psychological one, and not a physical one.

For all the studied traits, our results are in agreement with what has been observed on fishes, and is actually observed in humans (see references in the Introduction section). Here, we found that ants consuming fluoxetine lost their olfaction, or have a reduced one. We so propose to examine, on fishes, rats, mice, and humans, if, under fluoxetine consumption, they also present some decrease of their olfactory perception. In general, attention should be paid to the more and more numerous and abundant drugs presently consumed, and consequently existing in the natural water. Before allowing the consumption of any drug, experiments should be made on several living organisms, and results largely communicated. The present work, as previous ones (references in the Introduction section), shows that ants can advantageously be used as biological models.

\section{Acknowledgments}

We are very grateful to Dr R. Cammaerts for having made the Mann-Whitney tests, for his patience while experimenting, and for his help in writing the manuscript.

\section{References}

Abramson, C. I., Wells, H., \& Janko, B. (2007). A social insect model for the study of ethanol induced behavior: the honey bee. In R. Yoshida (Ed.), Trends in Alcohol Abuse and Alcoholism Research (pp. 197-218). Nova Sciences Publishers, Inc.

Andre, R. G., Wirtz, R. A., \& Das, Y. T. (1989). Insect Models for Biomedical Research. In A. D. Woodhead (Ed.), Nonmammalian Animal Models for Biomedical Research (November 13, 2008). Boca Raton, FL: CRC Press.

Antidépresseur. (ND). In Wikipedia, the free encyclopedia. Retrieved from http://fr.wikipedia.org/wiki/Antidépresseur

Antidépresseurs. (2014). In Psycom, information et sante mentale. Retrieved from http://www.psycom.org/ Medicaments/Antidepresseurs

Billen, J., \& Morgan, E. D. (1998). Pheromone communication in social insects - sources and secretions. In R. K. Vander Meer, M. D. Breed, K. E. Espelie, \& M. L. Winston (Eds.), Pheromone Communication in Social Insects: Ants, Wasps, Bees, and Termites (pp. 3-33). Boulder, Oxford: Westview Press.

Brodin, T., Fick, J., Jonsson, M., \& Klaminder, J. (2013). Dilute Concentrations of a Psychiatric Drug Alter Behavior of Fish from Natural Populations. Science, 339, $n^{\circ}$ 6121, 814-815. http://dx.doi.org/10.1126/science.1226850

Cammaerts, M.-C. (2004). Some characteristics of the visual perception of the ant Myrmica sabuleti. Physiological Entomology, 29, 472-482. http://dx.doi.org/10.1111/j.0307-6962.2004.00419.x

Cammaerts, M.-C. (2007). Colour vision in the ant Myrmica sabuleti MeINERT, 1861 (Hymenoptera: Formicidae). Myrmecological News, 10, 41-50.

Cammaerts, M.-C. (2008). Visual discrimination of cues differing as for their number of elements, their shape or their orientation, by the ant Myrmica sabuleti. Biologia, 63, 1169-1180. http://dx.doi.org/10.2478/s11756-008-0172-2

Cammaerts, M.-C. (2012). Navigation system of the ant Myrmica rubra (Hymenoptera, Formicidae). Myrmecological News, 16, 111-121.

Cammaerts, M.-C. (2013a). Ants' learning of nest entrance characteristics (Hymenoptera, Formicidae). Bulletin of Entomological Research, 6. http://dx.doi.org/10.1017/S0007485313000436 
Cammaerts, M.-C. (2013b). Learning of trail following behaviour by young Myrmica rubra workers (Hymenoptera, Formicidae). ISRN Entomology, Article ID 792891, 2013b, 6 pages.

Cammaerts, M.-C. (2014). Learning of foraging area specific marking odor by ants (Hymenoptera, Formicidae). Trends in Entomology, 10, 11-19.

Cammaerts, M. C. (2014). Performance of the species-typical alarm response in young workers of the ant Myrmica sabuleti is induced by interactions with mature workers. Journal of Insect Sciences, 14(1). http://dx.doi.org/10.1093/jisesa/ieu096

Cammaerts, M.-C., \& Cammaerts, D. (2009). Light thresholds for colour vision in the workers of the ant Myrmica sabuleti (Hymenoptera: Formicidae). Belgian Journal of Zoology, 138, 40-49.

Cammaerts, M. C., \& Cammaerts, D. (2014). Comparative outlook over physiological and ecological characteristics of three closely-related Myrmica species. Biologia, 69(8), 1051-1058. http://dx.doi.org/10.2478/s11756-014 $-0399-\mathrm{z}$

Cammaerts, M.-C., \& Cammaerts, R. (2014). Physiological and ethological effects of morphine and quinine, using ants as biological models. Journal of Pharmaceutical Biology, 4, 43-58.

Cammaerts, M.-C., \& Gosset, G. (2014a). Impact of age, activity and diet on the conditioning performance in the ant Myrmica ruginodis used as a biological model. International Journal of Biology, 6(2), 10-20. http://dx.doi.org/ 10.5539/ijb.v6n2p10

Cammaerts, M.-C., \& Gosset, G. (2014b). Ontogenesis of visual and olfactory kin recognition, in the ant Myrmmica sabuleti (Hymenoptera, Formicidae). Annales de la Société Entomologique de France, 50, 1-19. http://dx.doi.org/10.1080/0003792271.2014.981406

Cammaerts, M.-C., \& Nemeghaire, S. (2012). Why do workers of Myrmica ruginodis (Hymenoptera, Formicidae) navigate by relying mainly on their vision? Bulletin de la Société Royale Belge d'Entomologie, 148, 42-52.

Cammaerts, M.-C., \& Rachidi, Z. (2009). Olfactive conditioning and use of visual and odorous elements for movement in the ant Myrmica sabuleti (Hymenoptera, Formicidae). Myrmecological news, 12, 117-127.

Cammaerts, M.C., Gosset, G., \& Rachidi, Z. (2014a). Some physiological and ethological effects of nicotine; studies on the ant Myrmica sabuleti as a biological model. International Journal of Biology, 6, 64-81.

Cammaerts, M.-C., Morel, F., Martino, F., \& Warzée, N. (2012b). An easy and cheap software-based method to assess two-dimensional trajectories parameters. Belgian Journal of Zoology, 142, 145-151.

Cammaerts, M.-C., Rachidi, Z., \& Cammaerts, D. (2011). Collective operant conditioning and circadian rhythms in the ant Myrmica sabuleti (Hymenoptera, Formicidae). Bulletin de la Société Royale Belge d'Entomologie, 147, 142-154.

Cammaerts, M.-C., Rachidi, Z., \& Gosset, G. (2014b). Physiological and ethological effects of caffeine, theophylline, cocaine and atropine; study using the ant Myrmica sabuleti (Hymenoptera, Formicidae) as a biological model. International Journal of Biology, 3, 64-84.

Cammaerts, M-C., \& Cammaerts, R. (1980). Food recruitment strategies of the ants Myrmica sabuleti and Myrmica ruginodis. Behavioural Processes, 5, 251-270. http://dx.doi.org/10.1016/0376-6357(80)90006-6

Cammaerts-Tricot, M-C. (1973). Phéromone agrégeant les ouvrières de Myrmica rubra. Journal of Insect Physiology, 19, 1299-1315. http://dx.doi.org/10.1016/0022-1910(73)90213-8

Cipriani, A., Furukawa, T. A., Salanti, G., Geddes, J. R., Higgins, J. P., Churchill, R., ... Barbui, C. (2009). Comparative efficacy and acceptability of 12 new-generation antidepressants: a multiple-treatments meta-analysis. Lancet., 373(9665), 746-58. http://dx.doi.org/10.1016/S0140-6736(09)60046-5

Hölldobler, B., \& Wilson, E. O. (1990). The ants. Springer-Verlag Berlin: Harvard University Press. http://dx.doi.org/10.1007/978-3 -662-10306-7

Keller, L., \& Gordon, E. (2006). La vie des fourmis (p. 204). Odile Jacob, Paris.

Keller, R. A. (2011). A phylogenetic analysis of ant morphology (Hymenoptera: Formicidae) with special reference to the Poneromorph subfamilies. Bulletin of the American Museum of Natural History, 355, 99. http://dx.doi.org/10.1206/355.1

Klaper R. (2013). Les poissons vivant dans des eaux contaminées par des antidépresseurs deviennent anxieux, anti-sociaux et peuvent développer des tendances meurtrières, confirme une étude réalisée par des chercheurs de 
l'université de Milwaukee-Wisconsin (USA). Retrieved from http://egora12.rssing.com/chan-15648280/ all_p1.html

Kolb, B., \& Whishaw, I. Q. (2002). Neuroscience \& cognition: cerveau et comportement. Eds Worth Publishers, New York, Basing Stoke, 635pp.

Lane, C. (2009). Comment la psychiatrie et l'industrie pharmaceutique ont médicalisé nos émotions. Flammarion.

Lecomte, E. (2014). 7 choses à savoir sur la présence de médicaments dans l'eau. Retrieved from http://www.sciencesetavenir.fr/nature-environnement/20140829.OBS7600/7-choses-a-savoir-sur-la-presencede-medicaments-dans-1-eau.html

Parent, H. (2011). Analyse de la responsabilité pénale des personnes faisant l'usage d'antidépresseurs et ayant commis des infractions criminelles en cours de traitement ou de servage. Éditions Revue de Droit de l'Université de Sherbrooke.

Passera, L. (2006). La véritable histoire des fourmis. Librairie Fayard (p. 340).

Passera, L., \& Aron, S. (2005). Les fourmis: comportement, organisation sociale et évolution. Les Presses Scientifiques du CNRC, Ottawa, Canada, 480 pp.

Rachidi, Z., Cammaerts, M.-C. \& Debeir, O. (2008). Morphometric study of the eye of three species of Myrmica (Formicidae). Belgian Journal of Entomology, 10, 81-91.

Russell, W. M. S., \& Burch, R. L. (2014). The Principles of Humane Experimental Technique. Johns Hopkins University.

Sauvé, S. (2011). Poissons sous antidépresseurs. Retrieved from http://www.quebecscience.qc.ca/actualites/ Poissons-sous-antidepresseurs

Siegel, S., \& Castellan, N. J. (1989). Nonparametric statistics for the behavioural sciences. Singapore: McGraw-Hill Book Company.

Simon, G. E. (2002). Evidence review: efficacy and effectiveness of antidepressant treatment in primary care. General Hospital Psychiatry, 24(4), 213-24. http://dx.doi.org/10.1016/S0163-8343(02)00198-6

Søvik, E., \& Barron, A. B. (2013). Invertebrate models in addiction research. Brain Behavior and Evolution, 82, 153-165. http://dx.doi.org/10.1159/000355506

Thomas, M. A., Joshi, P. P., \& Klaper, R. D. (2012). Gene-class analysis of expression patterns induced by psychoactive pharmaceutical exposure in fathead minnow (Pimephales promelas) indicates induction of neuronal systems, Comparative Biochemistry and Physiology, part C, Toxicology and Pharmacology, 155(1), 109-120. http://dx.doi.org/10.1016/j.cbpc.2011.05.014

Wehner, R., \& Gehring, W. (1999). Biologie et physiologie animales. Eds. De Boek Université, Thieme Verlag, Paris, Bruxelles, 844 pp.

Wolf, F. W., \& Heberlein, U. (2003). Invertebrate models of drug abuse. Journal of Neurobiology, 54, 161-178. http://dx.doi.org/10.1002/neu.10166

\section{Copyrights}

Copyright for this article is retained by the author(s), with first publication rights granted to the journal.

This is an open-access article distributed under the terms and conditions of the Creative Commons Attribution license (http://creativecommons.org/licenses/by/3.0/). 